International Research Journal of Management, IT \& Social Sciences
Available online at https://sloap.org/journals/index.php/irjmis/
Vol. 6 No. 5, September 2019, pages: 204 209
ISSN: 2395-7492
https://doi.org/10.21744/irjmis.v6n5.729

\title{
Digital Marketing As Promotion on Bali Jeep Adventure Products
}

Putu Ratna Juwita Sari a

Article history:

Received: 18 March 2019

Accepted: 31 July 2019

Published: 03 September 2019

\section{Keywords:}

adventure; digital marketing;

marketing;

package tour;

strategic;

\begin{abstract}
Bali is one of the famous tourist destinations in the world, so there are many tourism actors offering tourism service and products to tourists who visit. One of the service providers in the form of a tour program is Bali Jeep Adventure which offers a back to nature program using a special 4WD car. Along with the development of technology and information, the marketing must be done through modern means, namely digital marketing using the internet. There are three main stages that must be carried out by Bali Jeep Adventure to maximize promotions through digital means, namely traffic, conversion, and engagement. This research uses qualitative descriptive methods, taking informants with purposive sampling and used triangulation of data aimed at obtaining data validity.
\end{abstract}

2395-7492@ Copyright 2019. The Author. This is an open-access article under the CC BY-SA license (https://creativecommons.org/licenses/by-sa/4.0/) All rights reserved.

\section{Author correspondence: \\ Putu Ratna Juwita Sari, \\ Universitas Pendidikan Nasional, Denpasar, Indonesia. \\ Email address: ratnajuwita@undiknas.ac.id}

\section{Introduction}

Tourism is one of the sources of state revenue in the non-oil and gas sector which has been declared capable of being an economic driver so that it can provide prosperity and welfare for its citizens if managed properly. Based on UNWTO data in 2015, tourism development has experienced continuous expansion and diversification to become one of the largest and fastest-growing economic sectors in the world (Rai, 2016; Yoga et al., 2019).

One of the favorite tourist destinations owned by Indonesia is the island of Bali which is famous for its natural beauty combined with the culture and customs of its people that is based on Hinduism. Bali's Original Regional Income is largely derived from the tourism sector, so the level of welfare of the people is very dependent on the development of tourism. Based on data on the number of tourist visits officially released by the Central Statistics Agency in June 2019 there were 549,751 foreign tourists coming to Bali both by air and sea transportation (Adetunji et al., 2017; Basak \& Khanna, 2017). This number has increased by $0.96 \%$ compared to June 2018 . The increase in the number of tourists is certainly supported by the increasing number of tourism service providers both from accommodation, restaurants and also travel service providers (BPS Propinsi Bali, 2018).

a Undiknas University, Denpasar, Indonesia 
Bali Jeep Adventure is a company that has been operating for 10 years and is engaged in providing natural tourism travel services using special vehicles, namely land lovers, which can be used to enter the forest and mountain areas in various places in Bali. The tour program offered is not only to enjoy the natural panorama but also to provide enjoyment for adventure lovers. In addition to foreign tourists, several national companies also entrusted their employee outing activities to this vendor (Gama et al., 2018; Aggarwal, 2017). As a company that is developing and facing fierce competition with similar companies, it is certainly necessary to promote so that more tourists use the services of Bali Jeep Adventure when visiting Bali. Promotion is carried out in the form of promotions carried out conventionally by collaborating with travel agents and distributing brochures. Digitally, this company already has a website and social accounts such as Facebook and Instagram. Given the development of marketing at this time, the promotion that should be prioritized is digital marketing (Jaminyasa et al., 2017; Ghosh \& Mukherjee, 2019).

Digital marketing is a thing that is experiencing rapid development along with the growth of internet users in the world. A variety of information and research can be obtained quickly, so this results in time efficiency for people who need a reference. Business actors also use the internet as a means of promotion that is cheaper and more effective than conventional promotions (Udayana, 2017; Ghosh, 2017).

Based on the explanation above, the purpose of this paper is to find out the effective utilization of digital marketing for the marketing of tourism products owned by Bali Jeep Adventure.

\section{Materials and Methods}

This study uses a qualitative descriptive method with data collection methods using observation, documentation and interview techniques. accounts Data validation is done by data triangulation technique that is matching data obtained from one research informant with another and adjusted to the research objectives so that the data obtained is valid.

\section{Results and Discussions}

Based on the data obtained through in-depth interviews of the Owner, Marketing and Bali Jeep Adventure reservation staff, some information was obtained that could support the following research. The results obtained are as follows:

a) Tour programs and the number of tourists who use the services of Bali Jeep Adventure

1) West Bali Adventure Off-Road

This tour program is an adventure activity by taking the route to the western part of Bali Island, Jembrana Regency. By using a 4WD car, tourists are invited to climb the hill and cross the river inside a rubber forest covering an area of 1200 hectares. Lunch will be served at a local restaurant after the end of the off-road activity.

2) Explore Batur Volcano

This Bali Jeep Adventure tour offers a unique view of Lake Batur that can be enjoyed from the top of Mount Batur after visiting the Geopark Museum in the Kintamani area. Tourists will be invited to pass the black lava rocks on the south side after a coffee break in the sea of sand located at the foot of Mount Batur. This tour program will be closed by a visit to the Hot Springs as well as lunch.

3) Jungle Fun Off-Road

The jungle fun off-road activity is held specifically for companies/groups that carry out outbound activities with a minimum of 20 participants. This tour program offers canoeing on Lake Beratan followed by lunch at a local restaurant and then carries out outbound activities on the edge of Lake Buyan located in the middle of protected forest. Coffee breaks are provided during outbound activities.

4) 4 WD Jungle Jeep Adventure

The 4 WD Jungle jeep adventure tour program is different from Jungle Fun Off-Road, because the program starts with doing soft trekking at Jatiluwih Rice Terrace, followed by visiting the Angseri Hot Spring. Lunch is served at a local restaurant before tourists are invited to enter the protected forest area in the Bedugul area.

5) Exotic 4X4 Bali Jeep Tour

Sari, P. R. J. (2019). Digital marketing as promotion on Bali jeep adventure products. International Research Journal of Management, IT and Social Sciences, 6(5), 204-209. https://doi.org/10.21744/irjmis.v6n5.729 
The 4X4 Bali Jeep Tour Exotic tour program starts by exploring the Batukaru Mountain area using ATV / quad, a vehicle designed for activities in nature that have been modified so that it is safe to use on muddy, rocky and slippery roads. After lunch, the activity was continued by visiting Angseri Hot Spring and then Jatiluwih Rice Terrace. The program is closed with a visit to the Margarana Heroes Cemetery located in Tabanan Regency.

6) 4X4 West Bali Land Cruise

The West Bali Land Cruise 4X4 tour program offers panoramic beauty of Belimbing Village, followed by coffee breaks and soft trekking. Furthermore, tourists will be invited to the rubber garden in Pekutatan, Jembrana district through Bunut Bolong, a large banyan tree with a hole in the middle that can be crossed by vehicles. Lunch will be served in a picnic-style before tourists are invited to explore the hills and rivers inside the rubber garden this.

7) Half-Day Jeep Tour to the South (Hidden Paradise)

In addition to offering a full-day tour, Bali Jeep Adventure also offers a Half day tour program starting after 13.00. One of them is a visit to the southern area of Bali which is named the Hidden Paradise Tour. The program starts with a coffee break in the Pura Gunung Payung area which has a view of the Indian Ocean. Furthermore, tourists are invited to visit Melasti Beach and pass Jimbaran Hill before tourists are dropped off at their respective restaurants or hotels.

8) Half-Day Jeep Tour to Ubud (Authentic Bali)

Another half-day tour product offered by Bali Jeep Adventure is to take the route to the Ubud area called Authentic Bali. The activity began with a soft off-road in Biaung Beach, followed by soft trekking in the rice fields and a coffee break served in Batubulan Village. Next, the tourists visit Tegenungan Waterfall before being dropped in the Ubud area.

9) Custom/Carter Tour

Custom/charter tours are tour activities planned by tourists without following a regular tour program or combining the tour with other activities.

Tabel 1

The average number of Bali Jeep Adventure tourists January - June 2019

\begin{tabular}{lll}
\hline Number & Tour Product & Number of Tourists \\
\hline 1 & West Bali Adventure Off-Road & 50 \\
2 & Explore Batur Volcano & 67 \\
3 & Jungle Fun Off-Road & 100 \\
4 & 4WD Jungle Jeep Adventure & 90 \\
5 & Exotic 4X4 Bali Jeep Tour & 25 \\
6 & 4X4 West Bali Land Cruise & 78 \\
7 & Half-Day Jeep Tour to the South (Hidden Paradise) & 76 \\
8 & Half-Day Jeep Tour to Ubud (Authentic Bali) & 85 \\
9 & Custom & 0 \\
\hline
\end{tabular}

Sources: Bali Jeep Adventure Reservation

Based on the table above, it can be seen that 4WD Jungle Jeep Adventure is the most popular program after the Jungle fun off-road program. The number of tourists increased by $0.3 \%$ from the previous year. Most of the tourists who come are first-time tourists and some are repeater guest who takes different programs from the previous program. Tourists find out about the Bali Jeep Adventure tour program from a travel agent and also by searching for information on the internet through the official Bali Jeep Adventure website by referring to reviews on the Online Travel Agent site such as TripAdvisor.

b) Digital marketing to increase the number of tourists who come

Every company will conduct promotions to market its products, including the Bali Jeep Adventure. Promotion according to Middleton is a short descriptive term of communication activities, both in person and through mass media that is done to influence people to buy a product. Promotion generally consists of advertising, sales promotion, and public relations, which are designed to achieve predetermined goals. 
Bali Jeep Adventure conventionally promotes by printing and distributing brochures, collaborating with travel agents and Tourist Information Centers. Promotional activities require large costs and a significant amount of time. Because of that Bali Jeep Adventure decided to also do promotions via the internet also known as digital marketing. Although this company already has an official website,www.balijeepadventure.com, social media such as Facebook, Instagram, and YouTube, its use has not been maximized.

Digital marketing is a very effective marketing strategy that pays attention to 3 main components, namely traffic, conversion, and engagement. Based on the research that has been done, it is very important for Bali Jeep Adventure to understand and implement the three main components as follows:

1) Traffic

What is meant by traffic is the number of website visitors or online property. What is meant by the online property is social media accounts such as Facebook, Instagram, blogs, forums and so on. The number of website visitors can be calculated through analytic tools provided freely by Google under the name Google Analytics for all website owners. The more people visit the website, the greater the opportunity to get consumers, or in this case is tourists.

Two things to consider in order to increase this traffic are content and advertising. What is meant by content is promotional products in the form of text, images, audio or video that are made as attractive as possible? While advertising or advertising is a promotional medium that should be made effectively and simply with the aim of bringing traffic to the website. Ads are chosen if the company cannot create content as a whole.

Content created by Bali Jeep Adventure must have a value or value from the content, which is used to determine the value and destination based on the tour product that has been created. In this case, the value that is owned is used to provide an experience that combines the beauty of nature with adventure, namely off-road activities and on a number of soft trekking tours so that tourists would be able to feel at one with nature. From the perspective of consumers, what is sought from content is what is it for me (WIIFM) or the benefits gained by tourists when buying a tour product at Bali Jeep Adventure. The content created must be able to attract the interest of tourists, which is why the website pages must contain detailed and creative explanations. On social media owned by Bali Jeep Adventure, photos and videos have been filled during the tour, both taken from testimonials and from photos taken by photographers hired to advertise. Appropriate media selection or distribution also plays a major role in marketing content. Seeing the market share of these tour products are aimed young people, it is only natural that the most widely used online media is Instagram.

\section{2) Conversion}

The next step after getting maximum traffic is to turn online media visitors into customers or what is called conversion. Conversion is divided into macro conversion, the main goal, in this case, is sales and potential buyers. Whereas micro conversion is something that website visitors do before making a purchase such as downloading brochure and making contact with producers.

There is always what is called a call-to-action (CTA), which is an invitation for website visitors to take action on the website in the form of buttons, forms, telephone numbers and so on. In addition, CTA also often uses solicitation sentences such as "Contact us now" or "Add to chart". Website performance can also be measured by looking at the number of visitors who made contact or reservations. On websites and other social media, Bali Jeep Adventure has implemented this CTA by filling in contact forms that can be filled out by potential tourists which contains their name, email and telephone number so that they can later be contacted again. In addition to the contact form, the key that makes it easy for prospective tourists to take some actions on the website such as the invitation to "Click to WhatsApp" or "Click to email". The available buttons must be interesting and connect directly with Bali Jeep Adventure reservation staff. Next, contact details are placed on the website pages to make it easier for potential tourists to contact the company. All Bali Jeep Adventure websites and social media have already contained the staff contact details that can be contacted.

3) Engagement

The relationship between producers and consumers in both conventional and digital marketing is important. After getting a lot of traffic and then converting it to the consumer using conversion, it then approaches to build relationships with each market segment consisting of repeat customers/repeat guests,

Sari, P. R. J. (2019). Digital marketing as promotion on Bali jeep adventure products. International Research Journal of Management, IT and Social Sciences, 6(5), 204-209. https://doi.org/10.21744/irjmis.v6n5.729 
buyers who first shop and also for prospective customers. Relationships are also built through social media, for example by using an Instagram account and Facebook Bali Jeep Adventure always invites its customers to follow and also posts photos/videos that contain the tourists concerned.

\section{Conclusion}

Based on the results and analysis above, it can be concluded that Bali Jeep Adventure has carried out the basic of digital marketing by creating websites and social media accounts to sell its products. But until now the development of the company's digital marketing has not been too optimal so that training is needed while also looking for marketers who are able to master technology and understand how to run digital marketing. The growth in the number of tourists that occurred from last year until now is thanks to the marketing that has been done digitally.

\section{Conflict of interest statement}

The authors declared that they have no competing interest.

\section{Statement of authorship}

The authors have a responsibility for the conception and design of the study. The authors have approved the final article.

\section{Acknowledgments}

Authors obtained lots of suggestions and encouragements from various parties, so on this occasion. Please allow me to thank:

1) Dr. Nyoman Sri Subawa, S.T., S.Sos., M.M., as the Rector of the Universitas Pendidikan Nasional Denpasar.

2) Dr. Ni Nyoman Juwita Arsawati, SH., M.Hum., as the Dean of the Faculty of Law and Social Sciences of Universitas Pendidikan Nasional Denpasar.

3) Owner, Reservation and Marketing staff of Bali Jeep Adventure

4) And all those who cannot be mentioned one by one by the author who has helped and supported the author in completing this report. 


\section{References}

Adetunji, A., Adetunji, A., Adeleke, E., \& Madubuike, S. (2017). Deregulation: the effect of market-led approach to Nigerian universities management. International Journal of Social Sciences and Humanities, 1(1), 1-8. https://doi.org/10.29332/ijssh.v1n1.6

Aggarwal, R. (2017). Different avenues of capital market (secondary market) available for investing in market of yamuna nagar. International Research Journal of Management, IT and Social Sciences, 4(3), 34-50.

Bali, BPS Provinsi. (2019). Statistik Wisatawan Mancanegara ke Bali 2018: BPS Provinsi Bali

Basak, A., \& Khanna, K. (2017). A study on the selection criteria of different hotels of Delhi NCR in accordance to the $\mathrm{hr}$ policies and market trends. International Journal of Social Sciences and Humanities, 1(1), 27-38. https://doi.org/10.29332/ijssh.v1n1.13

Gama, A. W. S., Rustiarini, N. W., \& Anggraini, N. P. N. (2018). Imaging and Purchasing Decision in Traditional Art Market. International Research Journal of Management, IT and Social Sciences, 5(2), 175-185.

Ghosh, C. (2017). A study on - evaluating marketing strategies adopted by home appliance for economic development in India. International Journal of Social Sciences and Humanities, 1(1), 9-15. https://doi.org/10.29332/ijssh.v1n1.7

Ghosh, C., \& Mukherjee, S. (2019). An exploratory study on marketing strategies of selected home appliances at kolkata metropolitan. International Journal of Social Sciences and Humanities, 3(2), 47-61. https://doi.org/10.29332/ijssh.v3n2.292

Jaminyasa, I. M., Pulawan, I. M., Martadiani, A. M., \& Amerta, I. M. S. (2017). The marketing mix affect on the consumer buying decision (case study of sausage products at PT. Aroma Denpasar). International Journal of Social Sciences and Humanities, 1(2), 65-74. https://doi.org/10.29332/ijssh.v1n2.44

Udayana, I. G. B. (2017). Marketing strategies arabica coffee with information technology in Kintamani District Bangli. International Research Journal of Engineering, IT \& Scientific Research, 3(3), 93-102.

Utama, I. G. B. R. (2017). Pemasaran Pariwisata. Penerbit Andi.

Yoga, I. M. S., Korry, N. P. D. P., \& Yulianti, N. M. D. R. (2019). Information technology adoption on digital marketing communication channel. International Journal of Social Sciences and Humanities, 3(2), 95-104. https://doi.org/10.29332/ijssh.v3n2.297

Sari, P. R. J. (2019). Digital marketing as promotion on Bali jeep adventure products. International Research Journal of Management, IT and Social Sciences, 6(5), 204-209. https://doi.org/10.21744/irjmis.v6n5.729 